\title{
IMPLEMENTASI METODE EXPERIENCE LEARNING SEBAGAI UPAYA PENINGKATAN KOMPETENSI PEMBELAJARAN MATAKULIAH PERILAKU ORGANISASI
}

\author{
Aniek Rumijati \\ Fakultas Ekonomi Universitas Muhammadiyah Malang \\ E-mail :rumijati@umm.ac.id
}

\begin{abstract}
This study aims to enhance knowledge, skills and attitude of students in learning. Organizational Behavior course. It is also an effort to increase student involvement in the learning process. By applying Learning Experience Method which place more emphasis on experience, students are able to feel, express and enhance personal development (soft skills). The method used was to compare the experience between the use of constructivist learning is a method in an experimental class using lecture and discussion on the control class.

Observations on the experimental class and control class obtained results indicate that the method is considered more interesting learning experience and fun, the involvement of students in the learning process more student skills can be improved and enhanced. In addition, if viewed from the aspect of student satisfaction attitudes towards learning experience methods showed higher yields than lecture method and discussion. Another indicator used is the value of midterm test and final test as an indication of the cognitive aspect or understanding of students in the experimental class obtained better results than the control class. The implication of this study found that use of the method of learning experience in Organizational Behavior course better than the lecture method and discussion
\end{abstract}

Keywords: experience, learning, constructivist, lectures and discussions

\section{PENDAHULUAN}

Mata kuliah perilaku organisasi adalah bagian dari bidang pengelolaan sumber daya manusia. Berkaitan dengan mata kuliah manajemen sumber daya manusia, pengembangan organisasi dan teori organisasi, mata kuliah ini selain memberikan pengetahuan dan pemahaman tentang konseptual, juga berisi pengembangan sikap dan kepribadian. Studi mengenai perilaku organisasi adalah studi dalam menganalisis dan menginterpretasikan perilaku dalam organisasi kerja. Oleh sebab itu dibutuhkan aplikasi sosiologi dan psikologi untuk memahami perilaku di tempat kerja (Tyson,-2000:2). Lebih lanjut Tyson menjelaskan bahwa perilaku organisasi dimaksudkan untuk mengintegrasikan disiplin ilmu psikologi, psikologi sosial, politik, sosiologi dan antropologi, sejauh disiplin ilmu tersebut berkaitan dengan orang di tempat kerja. Sedangkan menurut Robbins (2002:9) perilaku organisasi adalah suatu bidang studi yang menyelidiki dampak perorangan, kelompok, dan struktur pada perilaku dalam organisasi dengan maksud menerapkan pengetahuan semacam itu untuk memperbaiki efektivitas organisasi. Dari beberapa pendapat di atas, dapat disimpulkan bahwa mata kuliah ini berisi tentang upaya meningkatkan ketampilan mahasiswa dalam memahami individu, kelompok dan desain organisasi sehingga efektivitas organisasi dapat ditingkatkan. Secara rinci, dalam mempelajari perilaku individu, dikemukakan dasar-dasar perilaku individual termasuk tipe-tipe kepribadian dan mengetahui jenisjenis pekerjaan yang sesuai dengan kepribadian, nilai sikap dan kepuasan kerja, motivasi, teamwork, perilaku kelompok, kepemimpinan, kekuasaan dan desain organisasi.

Mempelajari teori perilaku organisasi tidak hanya sebagai pengetahuan atau kognitif, tetapi juga pengembangan sikap dan kepribadian atau soft skill serta ketrampilan mahasiswa. Mengingat bahwa mata kuliah ini juga diharapkan mampu meningkatkan tidak saja pengetahuan atau knowledge mahasiswa, tetapi juga pengembangan kepribadian atau attitude dan ketrampilan atau skill mahasiswa (KSA), maka 
dibutuhkan metode pengajaran yang lebih variatif, inovatif dan melibatkan mahasiswa dalam proses pembelajarannya. Selama ini metode ceramah dan diskusi lebih banyak digunakan. Dengan metode ceramah, tingkat kebosanan menjadi lebih tinggi, materi yang dapat diserap hanya maksimal 20 menit pertama yang disampaikan dosen, selanjutnya mahasiswa tidak dapat berkonsentrasi dengan baik. Selain itu dengan metode pembelajaran dengan teknik ceramah, materi hanya mampu diserap sebanyak $20 \%$. Menurut Unesco Tingkat belajar dapat dirumuskan dalam kerucut pengalaman belajar, yang menunjukkan bahwa mahasiswa belajar hanya $10 \%$ dari apa yang dibaca, 20\% dari apa yang didengar, $30 \%$ dari apa yang dilihat, $50 \%$ dari apa yang dilihat dan didengar, $70 \%$ dari apa yang dikatakan, dan $90 \%$ dari apa yang dikatakan dan dilakukan.

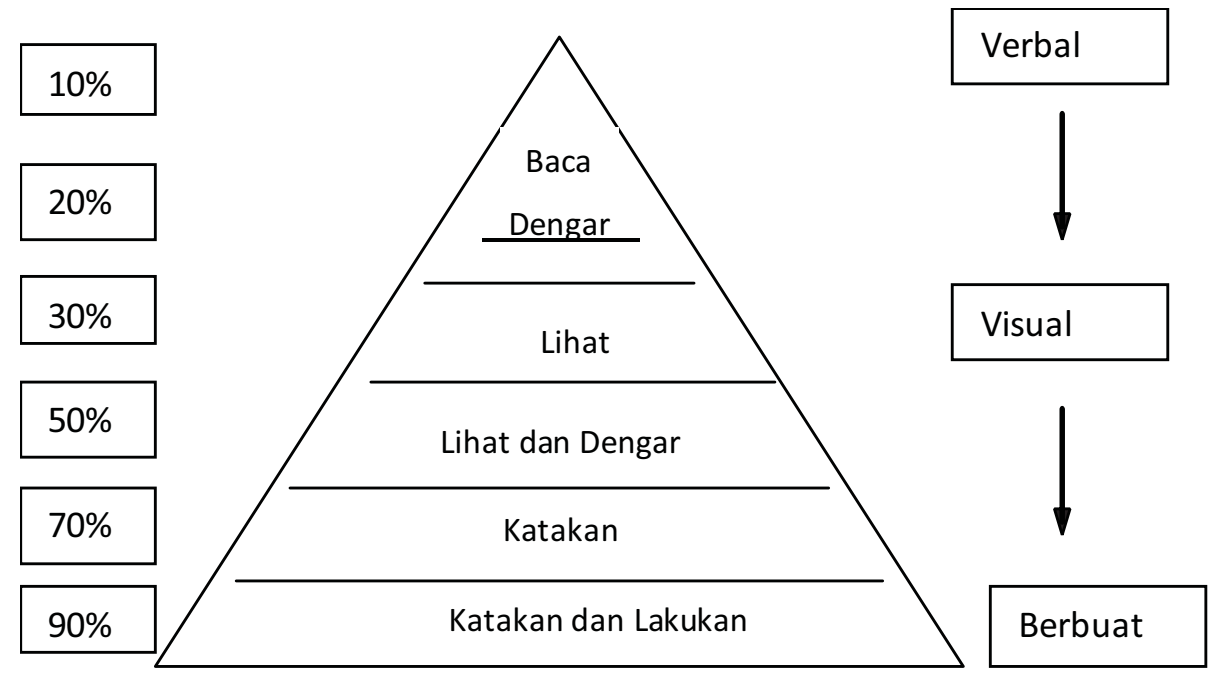

Gambar 1 : Kerucut Pengalaman Belajar

Metode ceramah, menurut Bligh (Zaini, 2002 :82) adalah continous expositions by speaker who wants the audience to learn something. Cranton mengisyaratkan bahwa metode ceramah identik dengan instuctur-centered method. Hal ini disebabkan dosen adalah satu-satunya orang yang bertanggung jawab terhadap penyampaian materi kepada mahasiswa, sehingga arah komunikasi cenderung hanya satu arah, yaitu dari dosen kepada mahasiswa. Kelemahan metode ini menurut Bligh adalah jika tujuan pembelajaran adalah mengubah sikap mahasiswa,maka sebaiknya tidak menggunakan metode ceramah, dan ceramah juga tidak efektif jika digunakan untuk mengajar ketrampilan. Metode ceramah dapat menjadi metode yang efektif, jika dipakai untuk pengajaran tingkatan yang rendah, yaitu pengetahuan dan pemahaman, dari pembelajaran ranah kognitif, terutama dari kelas besar.

Metode experience learning, menurut Zaini (2002:2) termasuk pembelajaran aktif. Pembelajaran aktif merupakan suatu pembelajaran yang mengajak mahasiswa belajar aktif. Ketika mahasiswa belajar dengan aktif, berarti mereka yang mendominasi aktivitas pembelajaran. Dengan ini mahasiswa aktif menggunakan otak, baik untuk menemukan ide pokok dari mata kuliah, memecahkan persoalan, atau mengaplikasikan apa yang baru mereka pelajari ke dalam satu persoalan yang ada dalam kehidupan nyata. Dalam model experience learnning sangat ditekankan pada aspek pengalaman, sehingga peserta didik membuat pengalaman, ekspresi, improvisasi dan penghayatan dalam proses belajar. Dengan belajar aktif ini, mahasiswa diajak untuk turut serta dalam semua proses pembelajaran, tidak hanya mental akan tetapi juga melibatkan fisik. Dengan cara ini mahasiswa akan merasakan suasana yang lebih menyenangkan sehingga hasil belajar dapat maksimal.

Metode lain yang dapat digunakan pada mata kuliah perilaku organisasi dan termasuk pada experience learning adalah metode self assessment. Melalui metode ini mahasiswa mampu mengenali diri mereka dan mengenal potensi serta kelemahan mereka. Metode ini digunakan untuk membahas materi kepribadian dan motivasi diri. Dengan mengetahui potensi diri yang dimiliki mahasiswa, diharapkan kelemahan-kelemahan yang ada dalam diri diubah menjadi kekuatan mereka. Sedangkan metode experience learning banyak digunakan untuk materi-materi lainnya, misalnya tentang motivasi, 
perilaku kelompok, teamwork, komunikasi dam kepemimpinan, dengan metode ini keterlibatan mahasiswa dapat lebih optimal, dan mahasiswa tidak hanya mempelajari dan memperoleh pengetahuan, tetapi juga merasakan dan menerapkan secara langsung terhadap materi-materi yang dibahas.

Didasarkan pada berbagai kelemahan dengan menggunakan metode ceramah atau tutorial dan metode diskusi yang digunakan selama ini, maka akan dibandingkan hasilnya dengan metode pembelajaran experience learning yang akan digunakan. Penerapan metode experience learning digunakan pada mata kuliah perilaku organisasi untuk mahasiswa yang menempuh pada kelas tertentu, yaitu dalam hal ini dianggap sebagai kelas experimen, sedangkan mahasiswa yang menempuh mata kuliah perilaku organisasi di kelas lainnya sebagai kelas kontrol, yaitu menggunakan metode ceramah dan diskusi. Penerapan yang berbeda ini dimaksudkan untuk mengetahui secara jelas perbedaan efektivitas metode pembelajaran yang digunakan.

Tujuan penerapan metode ini sebagai upaya untuk memperbaiki metode pembelajaran yang selama ini digunakan. Adapun tujuannya meliputi : (1) Untuk mengetahui apakah metode experience learning mampu meningkatkan pengetahuan, sikap dan ketrampilan mahasiswa. (2) Untuk mengetahui apakah metode experience learning mampu meningkatkan keterlibatan mahasiswa dalam peningkatan proses belajar. (3) Untuk mengetahui apakah metode experience learning mampu meningkatkan pengembangan kepribadian.

Adapun luaran penerapan metode ini diharapkan sebagai berikut : (1) Efektivitas Metode experience learning dalam hasil belajar Mata kuliah Perilaku Organisasi. (2) Efisiensi pembelajaran berbasis experience learning dalam proses pembelajaran mata kuliah Perilaku Organisasi yang aktif, kreatif dan inovatif. (3) Model experience learning dalam Pembelajaran mata kuliah Perilaku Organisasi sebagai aplikasi berba-sis Kompetensi.

\section{TINJAUAN PUSTAKA}

Penelitian serupa telah dilakukan oleh Yanti (2008) dengan menggunakan metode diskriptif dan pengumpulan data dengan pengamatan selama proses pembelajaran dan penyebaran kuesioner serta rekaman video, diperoleh hasil bahwa secara umum peserta menyatakan menarik dan sangat menarik terhadap model pembelajaran roda pesertaan. Hasil penelitian lain menemukan bahwa makin menarik penyampaian materi, makin bertambah wawasan dan pengetahuan peserta baik terhadap materi dan strategi pembelajaran. Sebanyak 98,3\% guru menyukai model pembelajaran ini, metode ini telah memberi ide pada mereka tentang aplikasi berbagai metode pembelajaran dan implementasi menunjukkan bahwa $82 \%$ aktivitas kegiatan belajar mengajar merupakan aktivitas mahasiswa, sedangkan aktivitas dosen dalam memberi eksplanasi hanya $12 \%$.

Persamaan penelitian terdahulu dengan yang dilakukan peneliti adalah penggunaan model pembelajaran berbasis student learning, yang sama-sama dipengaruhi oleh aliran konstruktivistik pendidikan. Selain itu metode pesertaan yang dilakukan oleh penelitian terdahulu termasuk dalam metode experience learning yang dilakukan juga oleh peneliti. Oleh karena itu posisi peneliti dalam hal ini adalah untuk mengetahui apakah memperoleh hasil penelitian yang serupa dengan metode experience dan penelitian ini membandingkan antara metode experience learning dan metode diskusi .

\section{Konsep Experience Learning}

Experience learning adalah suatu metode pembelajaran dengan keterlibatan mahasiswa yang tinggi. Experience learning menurut Rogers (1999:106) ...." Of a learning cycle starting with experience, proceeding through reflection on experience, and leading to action which is turn becomes the concrete experience for further reflection and thus next stage of this cycle"

Dalam pembelajaran experience learning, tanggung jawab untuk belajar ada pada mahasiswa, sebagai orang yang belajar. Mahasiswa akan menentukan sasaran belajar, dan hal ini akan mempengaruhi bagaimana kelas dalam mencapai tujuan belajar. Konsep experience learning, seperti pendapat dari Harvey ( 2003:21) didasarkan pada 3 konsep dasar, yaitu : (1). you learn best when you are involved in the learning experienceconsepts have to be experienced if discovered by you, the learner, if they are to change your behavior (2). your commitment to learning will be greatest when you are responsible for setting your own learning objectives

Sedangkan proses experiental learning ditunjukkan oleh empat tahapan menurut (Harvey:2003:23) sebagaimana ada pada gambar 3. 


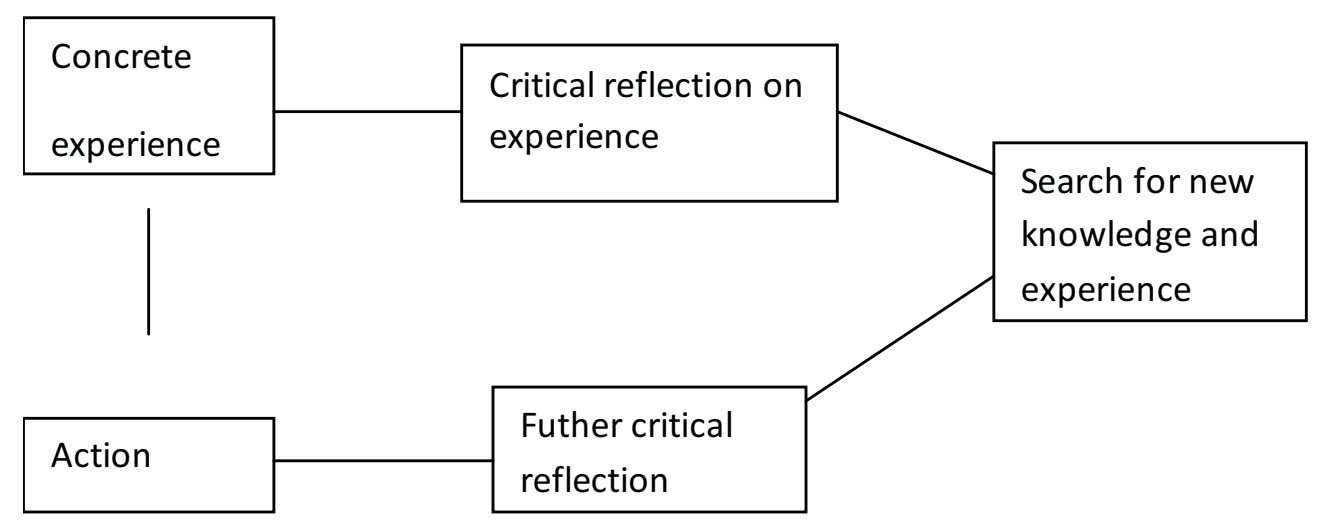

Gambar 2 : The learning cycle and the search for new knowledge

Sumber : Rogers (2003:108)

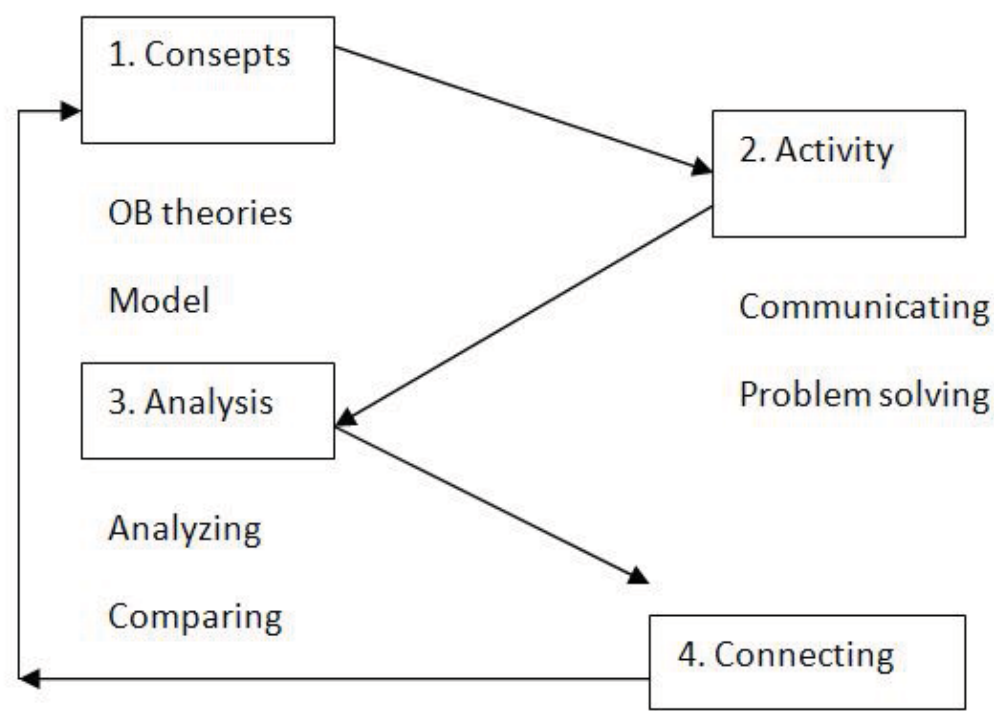

Gambar 3 : Schematic Diagram of Experiental Learning Cycle

\section{Hipotesis :}

Adapun hipotesis adalah sebagai berikut :

1) Diduga metode experience learning dapat meningkatkan pengetahuan, sikap dan ketrampilan mahasiswa .

2) Diduga metode experience learning dapat meningkatkan keterlibatan mahasiswa dalam proses belajar mengajar

3) Diduga metode experience learning dapat meningkatkan pengembangan kepribadian

\section{METODE PENELITIAN}

Metode experience learning termasuk model pembelajaran student-centered learning.Penelitian bersifat deskriptif, yaitu memberi gambaran tentang
(1) pelaksanaan model pembelajaran experince learning dan efektivitas serta efisensi pembelajarannya (2) membandingkan dengan pelaksanaan model pembelajaran menggunakan metode konvensional yaitu ceramah dan diskusi. Pengumpulan data dilakukan dengan cara pengamatan selama proses pembelajaran dan penyebaran kuesioner pada mahasiswa untuk mengetahui sikap atau kepuasaan terhadap masingmasing metode yang digunakan. Analisis data menggunakan analisis diskriptif.

\section{Prosedur}

Prosedur yang digunakan terdiri dari beberapa tahap: (a) Perencanaan, pada tahap awal yaitu menyiapkan materi dan bahan ajar yang digunakan 


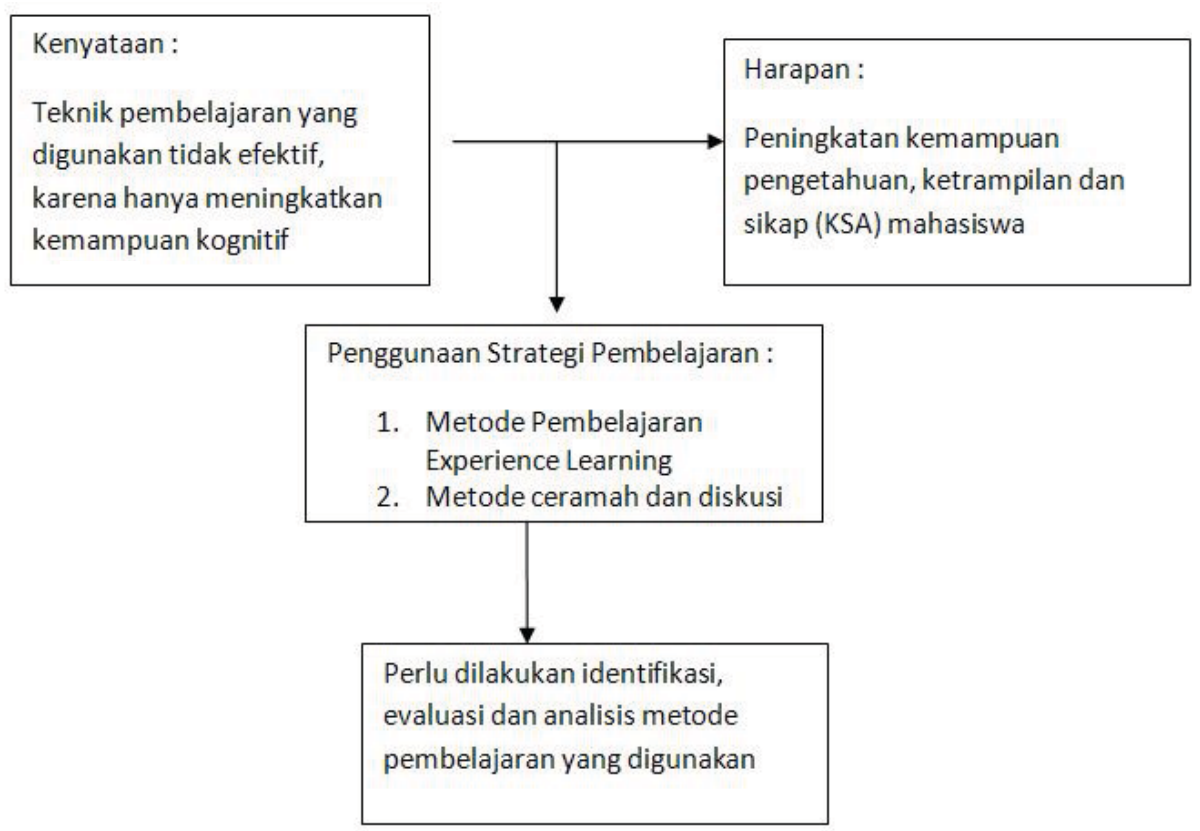

\section{Gambar 4 : Kerangka pemikiran}

untuk mendukung pembelajaran. Persiapan terdiri tindakan yang dilakukan mahasiswa di dalam kelas. dari mencari bahan yang dibutuhkan untuk mata Adapun materi dan teknik pembelajaran yang kuliah perilaku organisasi. (b) Implementasi, yaitu digunakan tertuang pada tabel 1.

Tabel 1: Materi dan Teknik Pembelajaran Yang Digunakan

\begin{tabular}{lll}
\hline NO & Materi & Teknik pembelajaran \\
\hline 1. & Gambaran Umum Perilaku Organisasi & Ceramah \\
2. & Dasar-dasar Perilaku Individu dan Kepribadian & Self Assesment \\
3. & Nilai, Sikap dan Kepuasan kerja & Experience Learning \\
4. & Persepsi dan Pengambilan keputusan individual & Experience Learning \\
5. & Konsep-konsep Motivasi & \\
6. & Perilaku Kelompok dan Team work & Experience Learning/Analisis Kasu \\
7. & Ujian Tengah Semester & Experience Learning \\
8. & Komunikasi & \\
\hline
\end{tabular}




\begin{tabular}{lll}
\hline 10 & Konflik dan Stress Kerja & Diskusi \\
11. & Dasar-dasar Struktur Organisasi & Analisis Kritis Kasus \\
12. & Budaya Organisasi & Analisis kasus \\
13. & Perubahan Organisasi & Ceramah \& Diskusi \\
14 & Ujian Akhir Semester & \\
\end{tabular}

Sumber : data primer

Pelaksanaan teknik pembelajaran disesuaikan dengan metode pembelajaran yang telah direncanakan. Pada dasarnya dipilih 3 teknik pembelajaran yang digunakan, yaitu Experience learning termasuk self assesment, analisis kritis terhadap objek atau kasus riil, sebagian kecil diskusi dan ceramah. Observasi, yaitu memantau kegiatan pembelajaran di kelas.

Pemantauan dilakukan melalui pengamatan secara intensif yang dilakukan setiap metode pembelajaran dilaksanakan dan dilakukan pencatatan. Adapun pengamatan meliputi: keterlibatan mahasiswa, reaksi mahasiswa terhadap materi dan metode pembelajaran yang digunakan, dan pemahaman mahasiswa pada materi yang diberikan. Sedangkan Refleksi, yaitu mengevaluasi dan menilai efektivitas pembelajaran yang telah dilakukan. Proses refleksi membuat peserta memahami manfaat, kelebihan dan kelemahan dari setiap tahapan kegiatan. Selanjutnya peserta dapat memperkirakan sikap dan tindakan bila menghadapi hal yang sama di kemudian hari.

\section{Indikator Kinerja}

Keberhasilan metode ini dapat dilihat dari :

1) keterlibatan mahasiswa dalam setiap perkuliahan

2) sikap mahasiswa terutama yang berkaitan dengan materi perku-liahan, misalnya disiplin, teamwork, leadership dan lain-lain

3) kemampuan untuk membuat sesuatu, inovatif, kreatif dst, misalnya tentang perilaku kelompok

4) nilai atau evaluasi hasil belajar mahasiswa baik UTS maupun UAS

\section{HASIL PENELITIAN DAN PEMBAHASAN}

\section{Gambaran Umum Objek}

Penelitian diadakan pada 2 kelas pengamatan, yaitu yang disebut sebagai kelas kontrol, dengan metode yang digunakan adalah metode ceramah dan diskusi, sedangkan kelas lainnya sebagai kelas eksperimen dengan menggunakan metode experience learning, analisis kritis dan diskusi. Pembedaan ini dimaksudkan sebagai bahan perbandingan untuk mengetahui diantara metode pembelajaran tersebut, manakah yang lebih efektif. Kriteria efektivitas, dilihat dari keterlibatan mahasiswa, tugas-tugas, nilai UTS dan nilai UAS. Jumlah mahasiswa pada kelas kontrol sebanyak 53 orang, sedangkan pada kelas eksperimen sebanyak 60 orang.

\section{Hasil Pengamatan pada Kelas Eksperimen :}

a. Keterlibatan mahasiswa dalam setiap perkuliahan.

Dengan menggunakan experience learning, análisis kritis dan self assesment semua mahasiswa ver-partisipasi aktif dalam setiap perkuliahan. Misalnya dalam materi self assesment, antara lain komunikasi, perilaku kelompok dan materi-materi lainnya semua mahasiswa terlibat secara aktif dan mampu mengeksplorasi kemampuan mereka secara optimal dalam mengerjakan tugas-tugas yang diberikan.

b. Sikap mahasiswa terhadap model pembelajaran

1).Model pembelajaran experience learning, analisis kritis dan diskusi. Mahasiswa bersikap positif terhadap model pembelajaran experience learning ini. Hasil kuesioner yang 
diberikan terhadap kelas kontrol dan kelas experimen menyatakan hasil yang berbeda. Pada kelas experimen, menyatakan bahwa cara penyampaian dengan menggunakan metode pembelajaran experience learning, termasuk self assesment sangat baik dan menarik dibandingkan dengan metode analisis kritis dan diskusi. Sedangkan pada kelas kontrol, dengan mengggunakan metode pembelajaran konvensional, yaitu diskusi dan ceramah menyatakan bahwa metode ceramah sedikit lebih disukai daripada metode diskusi

Sikap dan kepuasan mahasiswa terhadap metode pembelajaran yang digunakan tertuang pada tabel 2 .

Tabel 2 : Hasil Kepuasan Mahasiswa pada Kelas Experimen

\begin{tabular}{llll}
\hline No & Metode & Mean & Standard deviasi \\
\hline 1 & Experience learning & 4,200 & 0,722 \\
2 & Self assesment & 4,075 & 0,764 \\
3 & Analisis kasus & 3,784 & 0,783 \\
4 & Diskusi & 3,588 & 1,004 \\
\hline
\end{tabular}

Sumber : data diolah

Tabel 2 di atas menunjukkan, dari hasil kuesioner dengan menggunakan skala pengukuran yaitu skala Likert dengan kategori sangat baik dengan skor 5 hingga tidak baik dengan skor 1 , diperoleh hasil bahwa metode experience learning mempunyai skor rata-rata 4,2 lebih tinggi dibandingkan dengan metode lain, yang berarti bahwa mahasiswa menyatakan model pembelajaran dengan metode ini dianggap baik dan menarik dibandingkan dengan metode lain. Standard deviasi untuk experience learning dengan nilai 0,722 lebih kecil dibandingkan dengan metode lain, menunjukkan bahwa keragaman jawaban mahasiswa lebih kecil dibandingkan dengan metode lain.

2) Diskripsi jawaban responden

Adapun secara terperinci jawaban responden untuk masing-masing metode pembelajaran sebagai berikut :

\section{(a) Metode Pembelajaran : Experience Learning}

Berdasarkan diskripsi jawaban responden tentang metode experience learning yang digunakan ditunjukkan oleh tabel 3.

\section{Tabel 3 : Pendapat mahasiswa tentang metode Experience Learning}

\begin{tabular}{lcc}
\hline Keterangan & Jumlah (orang) & Persentase (\%) \\
\hline Tidak Baik & - & - \\
Cukup baik & 9 & 17,3 \\
Baik & 23 & 44,2 \\
Sangat baik & 19 & 36,5 \\
\hline Total & 51 & 100 \\
\hline
\end{tabular}

Sumber: data diolah

(b) Metode Pembelajaran :

\section{Analisis Kritis}

Sedangkan dengan metode analisis kritis terhadap kasus yang diberikan atau bahan ajar yang ditugaskan, pendapat mahasiswa tertuang pada tabel 3 .
Dari kedua hasil kuesioner tersebut, dapat disimpulkan bahwa sebagian besar mahasiswa menyatakan metode pembelajaran experience learning dan analisis kasus yang digunakan adalah baik. Metode analisis kasus yang digunakan pada 
Tabel 4 : Pendapat mahasiswa tentang Metode Analisis Kasus

\begin{tabular}{lcc}
\hline Keterangan & Jumlah & Persentase (\%) \\
\hline Tidak baik & 1 & 1,9 \\
Cukup baik & 16 & 30,8 \\
Baik & 26 & 50 \\
Sangat baik & 8 & 15,4 \\
\hline Total & 51 & 100 \\
\hline
\end{tabular}

beberapa materi pada perilaku oranisasi bertujuan untuk mengembangkan kecakapan menganalisis kritis, mengembangkan kemampuan mengambil kesimpulan yang masuk akal dari pengamatan dan belajar mengevaluasi bahan-bahan, metode-metode dan materi dalam mata kuliah

\section{(c) Metode Pembelajaran : Diskusi dan ceramah}

Metode diskusi dan ceramah adalah metode konvensional yang biasa digunakan. Metode ini digunakan pada materi tertentu, dengan tujuan agar dapat dibandingkan sikap dan kepuasan mahasiswa terhadap berbagai metode pembelajaran yang ada. Tanggapan mahasiswa terhadap metode diskusi yang digunakan dan ulasan dosen atau ceramah yang diberikan ada pada tabel 5 .

Metode diskusi, lebih disukai pada mahasiswa yang aktif dan berani mengungkapkan pendapat atau mempunyai kemampuan verbal yang lebih baik, tetapi tidak disukai bagi mahasiswa yang tidak aktif. Hanya sebagian kecil saja mahasiswa yang terlibat dalam diskusi dan sebagian lainnya kelihatan bosan atau melakukan kegiatan lain yang tidak berhubungan dengan pembelajaran. Diskusi seringkali tidak mempunyai konsep pembicaraan yang terarah, sehingga dosen perlu memberikan ulasan untuk memberikan pemahaman terhadap materi yang diberikan pada pertemuan tersebut.

\section{Hasil Pengamatan pada kelas Kontrol :}

Pelaksanaan metode pembelajaran pada kelas kontrol ini dengan menggunakan diskusi dan diakhiri oleh ulasan dosen atau ceramah dosen.Hasil pengamatan terhadap kelas kontrol, ditinjau dari keterlibatan mahasiswa, sikap dan kepuasaan mahasiswa sebagai berikut :

a. Keterlibatan mahasiswa dalam setiap perkuliahan

Pada kelas ini, diskusi merupakan hal yang utama selama proses pembelajaran. Sebagian besar waktu (berkisar \pm 75 menit) dari pertemuan di gunakan untuk mendiskusikan materi yang direncanakan berdasarkan Silabi. Satu kelompok yang telah ditetapkan sebelumnya, memperesentasikan hasil ringkasan mereka terhadap materi tertentu, kemudian diadakan tanya jawab dengan peserta lainnya. Diskusi di pimpin oleh salah satu mahasiswa yang bertindak sebagai moderator. Dosen mengamati jalannya diskusi dan mencatat semua hasil diskusi. Kemudian di akhir pertemuan dosen memberikan ulasan pada materi yang di diskusikan. Dari hasil pengamatan, diketahui bawa:(1) diskusi sering menjadi tidak efektif, tidak teratur dan tidak terarah karena anggota kelompok atau peserta diskusi berbicara tentang aspek yang berbeda dengan yang dibicarakan, diskusi menjadi meluas dan tidak fokus pada materi yang dibahas,

Tabel 5 : Pendapat mahasiswa tentang Metode Diskusi dan Ceramah

\begin{tabular}{lcc}
\hline Keterangan & Jumlah (orang) & Persentase ( \% ) \\
\hline Tidak baik & 1 & 1,9 \\
Kurang baik & 5 & 9,6 \\
Cukup baik & 19 & 36,5 \\
Baik & 15 & 28,8 \\
Sangat baik & 11 & 21,6 \\
\hline Total & 51 & 100 \\
\hline
\end{tabular}

Sumber: data diolah 
(2) hanya sebagian kecil mahasiswa yang berpartisipasi pada diskusi, dan beberapa mahasiswa mendominasi atau berbicara banyak sekali.

b. Sikap mahasiswa terhadap model pembelajaran

Sikap mahasiswa terhadap model pembelajaran diskusi dan ceramah dapat diketahui dari pendapat mahasiswa tentang bagaimana metode pembelajaran diskusi dan ceramah yang selama ini digunakan. Dengan mengggunakan metode pembelajaran konvensional, yaitu diskusi dan ceramah menyatakan bahwa metode ceramah atau penjelasan dosen tentang materi sedikit lebih disukai daripada metode diskusi artinya ulasan dosen dianggap lebih baik daripada metode diskusi. Adapun pendapat mahasiswa terhadap model pembelajaran dikemukakan pada tabel 6 .

c. Diskripsi jawaban responden pada kelas kontrol Untuk memperjelas tanggapan mahasiswa pada

Tabel 6 : Hasil kuesioner sikap dan kepuasan mahasiswa pada kelas kontrol

\begin{tabular}{cccc}
\hline No. & Metode & Mean & Standard deviasi \\
\hline 1 & Tutorial/ceramah & 3,9393 & 0,74747 \\
2 & Diskusi & 3,8182 & 0,98281 \\
\hline
\end{tabular}

Sumber : data diolah

kelas kontrol terhadap metode diskusi dan ceramah ditunjukkan hasil pada tabel 7 .

Tabel 7 diatas, menunjukkan bahwa tanggapan mahasiswa terhadap metode ceramah adalah 1 orang atau $3 \%$ menyatakan kurang baik, 7 orang atau $21,2 \%$ menyatakan cukup baik, 18 orang atau $54,5 \%$ menyatakan baik dan 7 orang atau 21,2\% menyatakan sangat baik. Sedangkan pendapat mahasiswa terhadap metode diskusi nampak pada tabel 8 .

Hasil ini menunjukkan bahwa pada sebagian mahasiswa masih mengharapkan dosen menjelaskan secara terperinci materi yang diberikan, daripada diskusi yang digunakan. Tidak semua mahasiswa merasa siap terhadap metode student center learning. Tanggapan ini terutama bagi mahasiswa yang tidak mempunyai keberanian untuk menyampaikan pendapat, ataupun kemampuan verbal mereka lemah. Selain itu tanggapan mahasiswa, yang berpendapat bahwa metode ceramah lebih baik daripada diskusi, berpendapat sama pada kelas kontrol yaitu menyatakan arah pembicaraan diskusi tidak terfokus pada materi, dan hanya didominasi sebagian kecil mahasiswa.

\section{d. Kerjasama}

Kerja sama kelompok pada mahasiswa dengan metode experience learning sangat nampak dibandingkan dengan metode konvensional, yaitu ceramah dan diskusi, karena tugas-tugas yang diberikan di kelas dan di rumah bersifat kelompok dan bukan tugas individual, hal ini memungkinkan semua mahasiswa terlibat di dalamnya sehingga kerjasama kelompok menjadi hal yang penting dalam penyelesaian tugas, sedangkan pada kelas kontrol tugas

Tabel 7 : Pendapat mahasiswa tentang metode ceramah

\begin{tabular}{lcc}
\hline Keterangan & Jumlah (orang) & Persentase ( \%) \\
\hline Tidak baik & - & - \\
Kurang baik & 1 & 3 \\
Cukup baik & 7 & 21,2 \\
Baik & 18 & 54,5 \\
Sangat baik & 7 & 21,2 \\
\hline Total & 33 & 100 \\
\hline
\end{tabular}

Sumber : data diolah 
Tabel 8 : Pendapat mahasiswa Tentang Metode Diskusi

\begin{tabular}{lcc}
\hline Keterangan & Jumlah (orang) & Persentase ( \% ) \\
\hline Tidak baik & 1 & 3 \\
Kurang baik & 1 & 3 \\
Cukup baik & 10 & 30,3 \\
Baik & 12 & 36,4 \\
Sangat baik & 9 & 27,3 \\
\hline Total & 33 & 100 \\
\hline
\end{tabular}

Sumber : data diolah

meresume hanya di kerjakan di rumah, sehingga tugastugas seringkali hanya dikerjakan oleh mahasiswa yang rajin, sedangkan yang malas tidak terlibat sama sekali.

e. Proporsi aktifitas selama proses belajar dan mengajar

Proporsi alokasi waktu selama proses belajar mengajar, menunjukkan bahwa waktu yang digunakan mahasiswa untuk beraktivitas ( 1 jam 40 menit 30 detik) lebih banyak daripada waktu yang digunakan dosen untuk bereksplanasi. Ini menunjukkan bahwa dosen bertindak sebagai fasilitator, dan mahasiswa telah belajar secara aktif dengan ratio 20/80. walaupun mahasiswa lebih banyak ber aktifitas mandiri, tetapi dosen tetap berperan dalam mengaktifkan pikiran mahasiswa dengan memberikan pertanyaanpertanyaan yang diberikan selama proses belajar mengajar berlangsung dan memberikan pengulasan diakhir pertemuan, agar selain aspek sikap dan ketrampilan yang diperoleh tetapi juga aspek kognitif atau pengetahuan yang berhubungan dengan materi dapat diperoleh dengan benar.

f. Kemampuan untuk membuat sesuatu yang inovatif, kreatif dan menarik
Pada materi-materi tertentu pada mata kuliah perilaku organisasi, misalnya perilaku kelompok mahasiswa diminta untuk membuat sesuatu barang dari kertas koran yang mempunyai nilai kreativitas, inovasi, dan mempunyai nilai jual yang tinggi. Dari hasil pengamatan diketahui bahwa mahasiswa menujukkan ketrampilan dan kemampuan serta kreativitas dan inovasi yang tinggi, misalnya membuat tas unik, pigura foto, topi dan barang lainnya. Selain itu mahasiswa diminta untuk mempromosikan barang yang dibuat kepada kelompok lainnya. Hal ini lebih mendorong mahasiswa memiliki keberanian tampil di depan mahasiswa lainnya, selain menimbulkan kepemimpinan pada jiwa seseorang.

g. Nilai atau evaluasi hasil belajar mahasiswa baik UTS maupun UAS

Hasil evaluasi ujian mahasiswa merupakan sebagai salah satu indikator keberhasilan model pembelajaran. Tabel 9 adalah hasil ujian tengah semseter pada kelas kontrol dan kelas eksperimen.

Dari hasil penelitian, diperoleh hasil bahwa nilai ujian tengah semester pada kelas eksperimen yaitu

Tabel 9 : Nilai Ujian Tengah Semester (UTS)

\begin{tabular}{lll}
\hline Kelas & Nilai rata-rata UTS & Standard deviasi \\
\hline Eksperimen & 64,57627 & 10,95792 \\
Kontrol & 64,24528 & 17,19225 \\
\hline
\end{tabular}

Sumber : data diolah

rata-rata 64,58 dengan standard deviasi sebesar 10,96. hasil ini lebih tinggi dari kelas kontrol, yaitu 64,25 dengan standard deviasi 17,19. Hasil ini menunjukkan bahwa hasil yang diperoleh pada kelas eksperimen lebih tinggi dengan standard deviasi lebih rendah.
Nilai ujian akhir semester, jika dibandingkan dengan nilai ujian akhir semester menujukkan peningkatan terutama pada kelas eksperimen. 
Tabel 10 : Nilai Ujian Akhir Semester (UAS)

\begin{tabular}{lll}
\hline Kelas & Nilai rata-rata UAS & Standard deviasi \\
\hline Eksperimen & 67,75 & 9,63 \\
Kontrol & 64,8111 & 12,82 \\
\hline
\end{tabular}

Sumber : data diolah

\section{Temuan}

Dari hasil penelitian yang telah dipaparkan diatas, dapat dikonsepsikan bahwa :

1. Bila dibandingkan antara 2 kelas yang ada, yaitu kelas kontrol dengan metode diskusi dan ceramah dan kelas experimen dengan menggunakan experience learning, diperoleh hasil bahwa keterlibatan, kerjasama, sikap atau kepuasan mahasiswa pada kelas experimen lebih tinggi daripada kelas kontrol. Selain itu metode ini dianggap lebih menyenangkan dan menarik $n$ mahasiswa membuat sesuatu barang, maka mahasiswa membuat barang yang kreatif dan inovatif. Dengan pembelajaran yang menyenangkan, maka secara aktif mengeksplorasi, dan membangun serta merangsang aspek ketrampilan, pengetahuan dan sikap mahasiswa.

4. Hasil penelitian ini mendukung hasil penelitian yang ditemukan Yanti (2008) yang menyatakan bahwa model pembelajaran roda pesertaan yang merupakan pengembangan dari model experience learning telah di apresiasi positif oleh para guru dan calon guru, meningkatkan keaktifan dan partispasi pembelajar dan pembelajar memperoleh gambaran bagaimana peranan pengajar sebagai fasilitator.

\section{SIMPULAN}

Model pembelajaran experience learning merupakan salah satu metode student center learning, yang dikategorikan sebagai model pembelajaran aktif.

Hasil penelitian ini diperoleh kesimpulan sebagai berikut:

a. Hasil penelitian menunjukkan bahwa dengan menggunakan metode experience learning dapat meningkatkan keterlibatan mahasiswa, dan pengetahuan mahasiswa disamping mengeksplorasi ketrampilan mahasiswa. b. Pendapat mahasiswa kelas eksperimen menyatakan bahwa model pembelajaran ini lebih menarik dibandingkan dengan metode analisis kritis terhadap kasus, dan metode diskusi dan ceramah. Hasil yang sama diperoleh, apabila dibandingkan pada kelas kontrol dengan metode pembelajaran pada kelas diskusi dan ceramah

c. Kerjasama, kepemimpinan dan inisiatif mahasiswa pada kelas yang menggunakan metode experience learning menjadi lebih tinggi bila dibandingkan dengan metode ceramah dan diskusi.

d. Dari aspek pengetahuan, hasil ujian baik ujian tengah semester dan ujian akhir semester pada kelas expe-rimen lebih tinggi diban-dingkan kelas kontrol, dan nilai standard deviasinya lebih kecil.

\section{Sedangkan saran sebagai berikut :}

a. Metode ini mengharapkan mahasiswa menjadi pembelajar yang aktif. Untuk itu disarankan, pada saat metode ini diterapkan diperlukan tahap persiapan yang lebih matang agar mahasiswa dapat mempelajari konsep teori yang dibahas terlebih dahulu. Sehingga mahasiswa mengetahui secara jelas tujuan dan sasaran pada setiap materi yang diberikan, sehingga student center learning benar-benar dapat efektif

b. Pada tahap pelaksanaan, dengan model experience learning mahasiswa ditekankan pada aspek pengalaman, ekspresi dan improvisasi dan pengahayatan dalam proses belajar. Hal ini merupakan salah satu pengembangan soft skill mahasiswa. Dengan jumlah mahasiswa yang lebih sedikit, model pembelajaran diharapkan menjadi lebih efektif khususnya dalam pengembangan pengetahuan, dan pengembangan kepribadian mahasiswa. Keberlanjutan pengembangan soft skill ini dapat dilakukan melalui pelatihan-pelatihan yang lain.

c. Pada tahap refleksi, disarankan dosen menarik kesimpulan dan memberikan penjelasan tentang teori. Pengalaman dan perasaan yang dirasakan 
dan konsep teori yang dibahas, membuat memori mahasiswa menjadi lebih kuat daripada hanya sekedar mendengarkan dengan menggunakan ceramah. Hasil ini mendukung penelitian Unesco atau Magsen 1983 dalam (de Porter,2000) yang menyatakan bahwa seseorang mengingat $90 \%$ dari yang dikatakan dan dilakukan.

\section{DAFTAR PUSTAKA}

Ad Rooijakskers, 1986. Mengajar dengan Sukses. Petunjuk untuk merencanakan dan Menyampaikan Pengajaran. Jakarta. : Penerbit PT.Gramedia

Dean A. Stephed .2002. Educating Entrepreneurship Students About Emotion and Learning From Failure. University of Colorado. Academy of Management Learning and Education, 2004, Vol. 3, No. 3, 274-287.

Gibson, 1998. Organisasi, Struktur dan Proses, Jakarta : Erlangga

Harvey, Donald F.et.al,. 2003. An Experiental Approach to Organization Development, fourth edition. Prentice Hall.

Rogers, Alan.1996. Teaching Adults, Philadelphia: Redwoor Books, Trowbridge, Wiltshire

Robbins, Stephen P.2002. Perilaku Organisasi. Jakarta : Prenhallindo

Yanti, 2008, Penerapan Model Pembelajaran Roda Pesertaan Pada Pelatihan Guru dan Pengajaran Calon Guru, Makalah diajukan pada simposium Puslijaknov 11-14 Agustus 2008

Zaini, Hisyam, 2002, Strategi Pembelajaran Aktif di Perguruan Tinggi, Yogyakarta 